\title{
The Effectiveness of Authentic Project-Based Assessment on the Online Learning System Toward Learning Result of Student Viewed from Critical Thinking Ability
}

\author{
Komang Hari Santhi Dewi ${ }^{1}$, I Nyoman Bagus Pramartha ${ }^{2}$ \\ \{santhi.dewi@stikom-bali.ac.id ${ }^{1}$, bagus.paramartha@stikom-bali.ac.id ${ }^{2}$ \} \\ Computer System Study Program, Faculty of Informatics and Computer, \\ Institut Teknologi dan Bisnis STIKOM Bali. Denpasar, Indonesia
}

\begin{abstract}
This study aims to recognize the effectiveness of authentic project-based assessment on the online learning system toward learning result of scientific writing methodology viewed from critical thinking ability. This research method was a quasiexperimental design with the posttest only control group design. The subjects of this study were students of STIKOM Bali academic year 2019/2020, and the sample was 80 students, which was divided into four classes. The research instrument consisted of a test of learning outcomes in scientific writing methodology courses and tests of critical thinking ability. The obtained data were calculated by using a one-way analysis of covariance (ANCOVA). The results showed that the learning outcomes of students who applied authentic projectbased assessments were higher than students who applied conventional assessments. The ability to think critically gives a positive contribution of $62 \%$ to student learning outcomes using authentic project-based assessments and a contribution of $48.1 \%$ to student learning outcomes using conventional assessment.
\end{abstract}

Keywords: authentic assessment, critical thinking, learning result, project

\section{Introduction}

The learning and assessment process are two crucial components in determining an educational program's success and quality. The learning process's effectiveness can be influenced by many factors, namely the selection of learning techniques or strategies, types of assessment, and application of learning technology. "The results of Cambridge International research through Global Education Census 2018 show that Indonesian students are very familiar with technology, not only social media but also for learning needs. The results of the study show that Indonesian students in computer space are the highest worldwide (40\%). In desktop computer use, they are also the second-highest in the world (54\%), after the United States [1]. Referring to this, many universities, including Indonesia, have long carried out online lectures as an implementation of digital-based learning. At ITB STIKOM Bali, online-based learning is combined with face-to-face meetings through e-learning services (virtual classes), scheduled according to the academic calendar. Lecturers in the ITB STIOM Bali environment have used e-learning to upload lecture material documents, assignments, quizzes, exams, and discussion forums. However, the use of media and online-based learning strategies is not always followed 
by the use of effective tests in assessing student learning outcomes. So far, the use of assessment still uses conventional assessment, namely assessment using written tests (theory courses) and practicum results (in lab/practicum subjects) at the end of the semester, so that in this way it is not optimal in revealing the quality of student learning outcomes from the aspects of attitudes and performance. Since the spread of the Coronavirus (COVID-19) pandemic in Indonesia in early March 2020, the ministry of education and culture has demanded that all levels of education carry out this online-based learning in full, which means that lecturers and students carry out lectures only through online media, both assignments and test execution. Thus, lecturers need to pay attention to the application of assessment in the online learning process to maximize student learning outcomes. Assessment is a systematic and systemic effort by collecting valid and reliable data or information to be processed as a basis for consideration in making decisions on an educational program. Given the importance of this assessment in determining learning success, authentic assessment can be used as an alternative in assessing learning outcomes in online learning systems. This is supported by research from Wijayanti (2014), which shows that authentic project-based assessment with a developed scientific approach can effectively improve scientific thinking skills. Overall, the increase in scientific thinking skills is 0.86 , which means the increase is with high criteria" [2]. The implementation of authentic assessment by project-based learning will enhance the problem solving skill of the student and high category concept mastery [3]. In learning through projects students conduct various activities to solve real-world problems and are responsible for making decisions based on the knowledge of various activities in the project [4]. To optimize the measurement of the quality of learning outcomes, it is necessary to pay attention to various aspects such as student skill profiles and subjects. In this study, the subject used as the object of research is the Scientific Writing Methodology course. By paying attention to learning strategies, teaching materials, and student conditions, the assessment used in this study is a project assessment. This project appraisal is useful for assessing general investigative skills, understanding, and student knowledge through critical thinking skills. Critical thinking ability are higher-order thinking skills that include behavioral tendencies and cognitive skills to solve problems, draw conclusions, calculate possibilities, and make decisions. The indicators of achieving the quality of student learning outcomes in the Scientific Writing Methodology course can be seen in the accumulated scores of assignments, quizzes, midterm exams, and final semester exams. Based on the analysis of the situation, research was carried out related to the effectiveness of authentic project-based assessment on the online learning system toward learning result of student viewed from critical thinking ability.

\section{Literature Review}

In essence, authentic assessment emphasizes holistic assessment to seek and explore information about the competence of students authentic in using their knowledge, attitudes, and skills in carrying out lecture assignments. Authentic assessment can also monitor prospective teachers' learning progress and motivate and provide opportunities for students to improve their work [5]. Assessment is a systematic and systemic effort that collects valid and reliable data or information to be processed as a basis for consideration in making decisions on an educational program [6]. The primary purpose of conducting an assessment or evaluation in the learning process is to obtain accurate information about the learning process level. Based on this information, a follow-up can be done, which is an evaluation function, in the form of proper 
placement, providing feedback, diagnosis of learning difficulties, and determining the increase in the level or graduation of education at certain levels of education.

Authentic assessment has relevance to scientific activities and approaches because this type of assessment can describe the improvement of student learning outcomes in a comprehensive manner in assessing input, process, and learning outcomes which consist of student knowledge, skills, and attitudes [7]. One type of authentic assessment that can be used to integrate students' analytical skills is an authentic project-based assessment. Expert opinion on project-based learning shows that the use of this learning model strongly supports the development of scientific capabilities [8]. A project-based assessment is a comprehensive assessment of the student's ability through assignments that contain investigations and must be completed within a certain time. This project assessment is useful for assessing general investigative skills, understanding and authentic assessment of process and product knowledge can be measured both relevant tasks and contextually measuring students' knowledge and skills" [2]. The application of authentic assessment can provide several benefits, such as identifying direct measurement of expected competency indicators of student performance; encourage students to demonstrate their performance in real and meaningful situations; allow students to build on their learning outcomes by selecting and structuring answers based on their knowledge and situational analysis so that the answers are relevant and meaningful; and integrating teaching, learning and assessment activities [9]. Project assessment-based learning can be combined with online-based e-learning so that students can complete projects with electronic media. The learning process with e-learning is beneficial for students to interact with lecturers and between students and can be done at any time, without being limited by time or place. Elearning is technology development in learning, namely by utilizing computers and other information devices such as multimedia and the internet [10]. In reality, there are still lecturers who judge students only from one aspect, namely cognitive aspects, for example, from written tests on final exams (semester exams). This assessment means only providing a momentary picture of student performance. The use of midtest and semester exams as benchmarks for student success only reflects the cognitive aspects' ability, while the affective and psychomotor aspects are not given attention. "Conventional assessment using tests is often outside the realworld context of students. The conventional assessment also does not fully describe student learning progress as a whole because the results given from this conventional assessment tend to be abstract numbers or letters" [11]. The differences between project-based assessment and conventional assessment are summarized in the following table:

Table 1. Comparison of Project-based Assessment and Conventional [12][13]

\begin{tabular}{ll}
\hline \multicolumn{1}{c}{ Project-based Assessment } & \multicolumn{1}{c}{ Conventional Assessment } \\
\hline $\begin{array}{l}\text { Concerned with the ability of students to apply } \\
\text { their knowledge into observable performance or } \\
\text { products }\end{array}$ & Prioritizes students' conceptual understanding \\
Time-consuming to create and implement but & $\begin{array}{l}\text { It takes a lot of time for the implementation to be } \\
\text { results in an assessment format that can be used }\end{array}$ \\
$\begin{array}{l}\text { faster and can be used for many students } \\
\text { over and over again with the same student or new }\end{array}$ & $\begin{array}{l}\text { simultaneously, but it is used only once for a group } \\
\text { of students. }\end{array}$ \\
$\begin{array}{l}\text { students } \\
\text { Allows to diagnose and remediate learner } \\
\text { performance and map student progress over time }\end{array}$ & $\begin{array}{l}\text { It is possible to diagnose and remediate student } \\
\text { performance but only for open-ended questions. }\end{array}$
\end{tabular}

Focusing learning on student performance and developing students ${ }^{\text {ee }}$ thinking skills.

Focusing learning on the subject matter 
In maximizing learning outcomes with project-based assessments, an essential aspect to consider is students' thinking ability. High-level thinking ability can be developed in the learning process, especially in learning mathematics, one of which is critical thinking. In the sense of learning, critical thinking is a thinking ability that students must build and master. Critical thinking is rational and reasonable thinking that is focused on making decisions about what to believe. Critical thinking ability are higher-order thinking skills that include behavioral tendencies and cognitive skills to solve problems, draw conclusions, calculate possibilities, and make s about what to believe or do. Most students can master learning material based on the concepts being taught. However, in some applicative problems, students sometimes erroneously answer and determine solutions to these problems. Students who think critically will be able to answer problems well. Besides, students who think critically can also use abstract ideas to be able to model problem-solving effectively. Assessment instruments that are well designed and following the level of thinking ability can improve students' thinking power, especially critical thinking [9]. Based on this definition, critical thinking is focused on higher-order thinking skills that include behavioral tendencies and cognitive skills to solve problem thinking ability recalculate possibilities, and make decisions about what to believe or do.

\section{Method}

This research method is a quasi-experimental design with posttest only control group design. The independent variable in this study is learning assessment which is divided into project-based authentic assessment and conventional assessment. The dependent variable in this study is the student learning outcomes in the scientific writing methodology subject, while the critical thinking ability is used as a controlling variable (covariable). Critical thinking skills data in the two research groups will be collected using the test method of critical thinking skills. Simultaneously, the measurement of learning outcomes is obtained after the completion of treatment in both the experimental class and the control class by using the learning outcome test method through project appraisal. This research uses a random sampling technique (random class). Two classes as the experimental group and the other two classes as the control group. In the experimental group, learning was applied by applying project assessment, and in the control group, group learning was applied by applying conventional assessment. The experimental group numbered 40 people, and the control class also numbered 40 people. Thus the total sample of the study was 80 students. This research uses descriptive quantitative analysis techniques. Before testing the hypothesis, a prerequisite test is carried out including data normality test, variant homogeneity test, linearity test and the testing of the regression line. The research hypothesis was tested using covariance analysis assisted by the SPSS 20.00 program at a significance level of 0.05 .

\section{Result and Discussion}

Therefore, the data in this study were grouped into four groups of data due to the treatment of the application of project-based authentic assessment and conventional assessment in terms of critical thinking skills. The data groups are; (1) data on student learning outcomes that apply authentic project-based assessments; (2) data on student learning outcomes that apply 
conventional assessment; (3) data on critical thinking skills of students who apply authentic project-based assessment, and (4) data on critical thinking skills of students who apply conventional assessment. Each group consisted of 40 subjects as the unit of analysis. Data descriptions relating to measures of central tendency such as calculated means, mode, median, and size of the spread of data (standard deviation) for all data groups are shown in the following table;

Table 2 The Results Of Descriptive Analysis Of Student Learning Outcomes And Critical Thinking Ability In Student Groups Who Apply Project-Based Authentic Assessment and Conventional Assessment

\begin{tabular}{lrrrr}
\hline & \multicolumn{2}{c}{$\begin{array}{c}\text { Project-Based Authentic } \\
\text { Assessment }\end{array}$} & \multicolumn{2}{c}{$\begin{array}{c}\text { Conventional } \\
\text { Assessment }\end{array}$} \\
\hline Statistic & $\begin{array}{c}\text { Critical } \\
\text { Thinking }\end{array}$ & $\begin{array}{c}\text { Student Learning } \\
\text { Outcomes }\end{array}$ & $\begin{array}{c}\text { Critical } \\
\text { Thinking }\end{array}$ & $\begin{array}{c}\text { Student Learning } \\
\text { Outcomes }\end{array}$ \\
\hline Total Number of Data & 40 & 40 & 40 & 40 \\
Mean & 129,50 & 87,85 & 87,50 & 75,23 \\
Median & 128,50 & 89,00 & 86,00 & 75,50 \\
Mode & 125,00 & 100,00 & 77,00 & 62,00 \\
Standar Deviation & 13,77 & 10,17 & 15,98 & 13,45 \\
Range & 50,00 & 38,00 & 64,00 & 54,00 \\
Minimum score & 101,00 & 62,00 & 61,00 & 46,00 \\
Maximum score & 151,00 & 100 & 125,00 & 100 \\
\hline
\end{tabular}

Based on the results of the descriptive analysis showed that the average score of student learning outcomes who implemented the Project-Based Authentic Assessment was higher than that of students who implemented the Conventional Assessment. When viewed from Critical Thinking, students who implement Project-Based Authentic Assessment are also higher than students who implement Conventional Assessment.

The results of the prerequisite analysis showed that the test data distribution normality results show that the probability value in Kolmogorov-Smirnov in the four groups is greater than the probability value of 0.05 . Thus the data distribution of learning outcomes and students' critical thinking ability in the group implementing authentic project-based assessment is normally distributed. The homogeneity test of variance was carried out using the application SPSS 20.0 observing the statistical value Lavene. The results of the homogeneity test of data variance on critical thinking ability and student learning outcomes in the group of students who implement authentic project-based assessments and conventional assessment shows that the data has a homogeneous variance with a value probability> 0.05 . A linearity test is conducted to determine the relationship between controlling variables, and the dependent variable is linear or not. The linear equation for students implementing authentic project-based assessments $\left(\mathrm{A}_{1}\right)$ is $\mathrm{Y}=24,814+0,482 \mathrm{X}$. While the linear equation for students implementing conventional assessment $\left(\mathrm{A}_{2}\right)$ is $\mathrm{Y}=17,274+0,657 \mathrm{X}$. The linearity test using the $\mathrm{F}$ test shows that the two data groups are linear and have directional coefficients.

The first hypothesis testing is to determine "the difference in the quality of learning outcomes between students who apply authentic project-based assessments and students who learn with a conventional assessment on online learning systems." The test was carried out using one-way ANOVA. The results of one-way ANOVA calculations with SPSS 20.0: 
Table 3. The results of one-way ANOVA Tests

\begin{tabular}{lrrrrr}
\hline & Type III Sum of & & & & \\
Source & Squares & df & & Mean Square & \multicolumn{1}{c}{ F } \\
\hline Corrected Model & 3187.813 & 1 & 3187.813 & 22.429 & .000 \\
Intercept & 531869.113 & 1 & 531869.113 & 3742.153 & .000 \\
A & 3187.813 & 1 & 3187.813 & 22.429 & .000 \\
Error & 11086.075 & 78 & 142.129 & & \\
Total & 546143.000 & 80 & & & \\
Corrected Total & 14273.888 & 79 & & & \\
\hline
\end{tabular}

Based on the output, the F value calculated $=22.429$ with a significant value less than 0.05. This means a difference in the quality of learning outcomes between students who apply authentic project-based assessments and students who learn with a conventional assessment of online learning systems. The second hypothesis testing is to determine "the difference in the quality of learning outcomes between students who apply authentic project-based assessments and students who learn with conventional assessment in online learning systems after controlling the covariable critical thinking skills." To test the second hypothesis, a one-way ANCOVA analysis was used with SPSS 20.0 with the following results:

Table 4. The Results Of One-Way ANCOVA Test

\begin{tabular}{lrrrrr}
\hline & Type III Sum of & & & & S \\
Source & Squares & df & & Mean Square & \multicolumn{1}{c}{ F } \\
\hline Corrected Model & 9287.940 & 2 & 4643.970 & 71.719 & .000 \\
Intercept & 428.931 & 1 & 428.931 & 6.624 & .012 \\
X & 6100.127 & 1 & 6100.127 & 94.207 & .000 \\
A & 993.614 & 1 & 993.614 & 15.345 & .000 \\
Error & 4985.948 & 77 & 64.753 & & \\
Total & 546143.000 & 80 & & & \\
Corrected Total & 14273.888 & 79 & & & \\
\hline
\end{tabular}

Based on the results of the analysis in Table 3, it is found that the value of $F=15.345$, and the significant value is less than 0.05 . This means a difference in the quality of learning outcomes between students who apply authentic project-based assessments and students who learn with conventional assessment in online learning systems after controlling the covariable critical thinking skills. The third hypothesis testing is carried out by simple regression analysis, namely by looking at the critical thinking ability variable's contribution to the learning outcomes in students who take learning with project assessment and conventional assessment. To see the magnitude of the contribution of the critical thinking ability variable to learning outcomes, it can be seen from the correlation coefficient $(r)$ and determination coefficient $\left(r^{2}\right)$. The contribution of students' critical thinking skills to student learning outcomes In the group that applies authentic project-based assessments, the value of the correlation coefficient is 0.787 , and the coefficient of determination is $\left(\mathrm{r}^{2}\right)$ of 0.620 . The value of $\mathrm{F}_{\text {ount }}=35,201$ with a significance value of 0.00 . This means a significant and predictive relationship between critical thinking skills and learning outcomes in students who apply authentic project-based assessments with a contribution weight of $62 \%$. The results of the analysis of the contribution of students' critical thinking skills to student learning outcomes. In the group that implemented the 
conventional assessment, the correlation coefficient was 0.693, and the determination coefficient was $\left(\mathrm{r}^{2}\right)$ of 0.481 . The value of $\mathrm{F}_{\text {ount }}=62.013$ with a significance value of 0.00 . Thus, it can be concluded that there is a significant and predictive relationship between critical thinking skills and learning outcomes in students who take lessons with conventional assessment with a contribution weight of $48,1 \%$.

From the distribution of response questionnaires distributed to students at the end of the study to find out the responses or responses of students to the application of the assessment given, it is known that as many as $27.50 \%$ of students responded very positively, $72.50 \%$ of students responded positively, and there were no students who responded sufficiently. positive, less positive, and very less positive towards Online Learning Model Using Project-Based Authentic Assessment. The results of student responses are shown in the following figure;

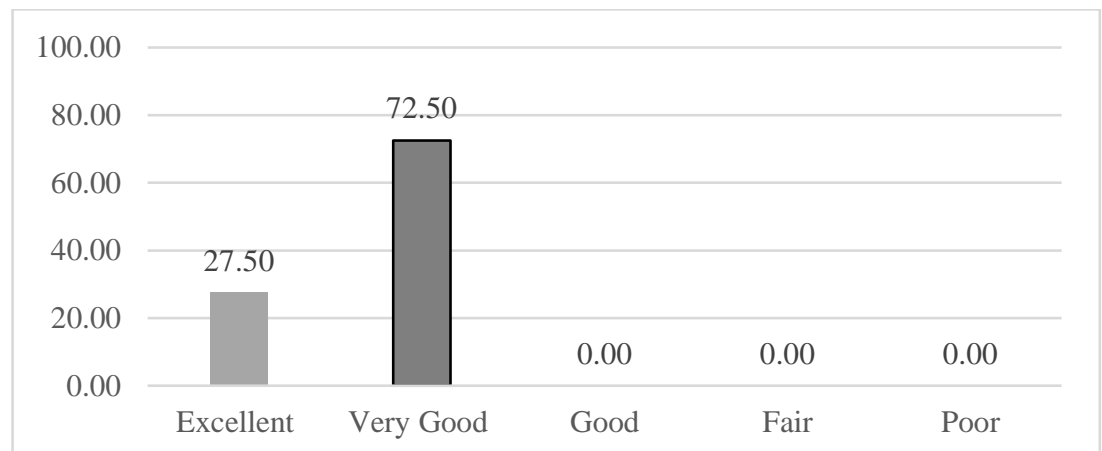

Figure 1. Student Responses to the Implementation of Project-Based Authentic Assessments

\section{Conclusion}

The results showed that: (1) There are differences in the quality of learning outcomes between students who apply authentic project-based assessments and students who study conventional assessments in online learning systems; (2) There are differences in the quality of learning outcomes between students who apply authentic project-based assessments and students who study conventional assessment on online learning systems in terms of critical thinking ability covariables. (3) The results showed that the learning outcomes of students who applied authentic project-based assessments were higher than students who applied conventional assessments. The ability to think critically gives a positive contribution of $62 \%$ to student learning outcomes using authentic project-based assessments and a contribution of $48.1 \%$ to student learning outcomes using conventional assessment.

\section{References}

[1] Cambridge Assessment International Education, "Indonesian Students Among the World's Highest Users of Technology," Cambridge Assessment International Education. $\quad$ pp. 26-27, 2018, [Online]. Available: https://www.cambridgeinternational.org/news/news-details/view/indonesian-studentsamong-the-worlds-highest-users-of-technology-27-nov2018/. 
[2] A. Wijayanti, "Pengembangan autentic assesment berbasis proyek dengan pendekatan saintifik untuk meningkatkan keterampilan berpikir ilmiah mahasiswa," J. Pendidik. IPA Indones., 2014, doi: 10.15294/jpii.v3i2.3107.

[3] M. Andanawarih, S. Diana, and A. Amprasto, "The implementation of authentic assessment through project-based learning to improve student's problem solving ability and concept mastery of environmental pollution topic," J. Phys. Conf. Ser., vol. 1157, no. 2, 2019, doi: 10.1088/1742-6596/1157/2/022116.

[4] J. Uziak, "A project-based learning approach in an engineering curriculum," Glob. J. Eng. Educ., vol. 18, no. 2, pp. 119-123, 2016.

[5] L. Yuliati, "ASESMEN AUTENTIK DALAM ACTIVE LEARNING UNTUK MEMONITOR KEMAJUAN BELAJAR CALON GURU FISIKA,” JPPS (Jurnal Penelit. Pendidik. Sains), 2017, doi: 10.26740/jpps.v2n1.p120-126.

[6] S. Ermawati and H. Taufiq, "Penilaian Autentik dan Relevansinya dengan Kualitas Hasil Pembelajaran (Persepsi Dosen dan Mahasiswa IKIP PGRI Bojonegoro)," J. Pendidik. Ilmu Sos., 2017.

[7] P. G. Wartawan, "The Effectiveness of the Use of Portfolio Assessment by Controlling Prior Knowledge to Enhance Scientific Attitude among Senior High School Students," Int. J. Phys. Sci. Eng., vol. 1, no. 3, pp. 9-18, 2017, doi: 10.21744/ijpse.v1i3.54.

[8] H. Hairida and T. Junanto, "The Effectiveness of Performance Assessment in ProjectBased Learning by Utilizing Local Potential to Increase the Science Literacy," Int. J. Pedagog. Teach. Educ., vol. 2, no. July, p. 17, 2018, doi: 10.20961/ijpte.v2i0.25722.

[9] R. G. Susani, "THE IMPLEMENTATION OF AUTHENTIC ASSESSMENT IN EXTENSIVE READING," Int. J. Educ., 2018, doi: 10.17509/ije.v11i1.9113.

[10] M. Jamaluddin and N. Faroh, "Developing authentic assessment: Project assessment on mathematics learning evaluation by using e-learning," Math Didact. J. Pendidik. Mat., 2020, doi: 10.33654/math.v5i3.729.

[11] I. W. E. Mahendra, "Contextual Learning Approach and Performance Assessment in Mathematics Learning," Int. Res. J. Manag. IT Soc. Sci., 2016, doi: 10.21744/irjmis.v3i3.88.

[12] C. L. Chiang and H. Lee, "The Effect of Project-Based Learning on Learning Motivation and Problem-Solving Ability of Vocational High School Students," Int. J. Inf. Educ. Technol., vol. 6, no. 9, pp. 709-712, 2016, doi: 10.7763/ijiet.2016.v6.779.

[13] Mahendra, "Asesmen Alternative Dalam Pembelajaran Matematika," Pros. Senama PGR, vol. 1, no. 87, 2019, doi: 10.5281/zenodo.3445646. 